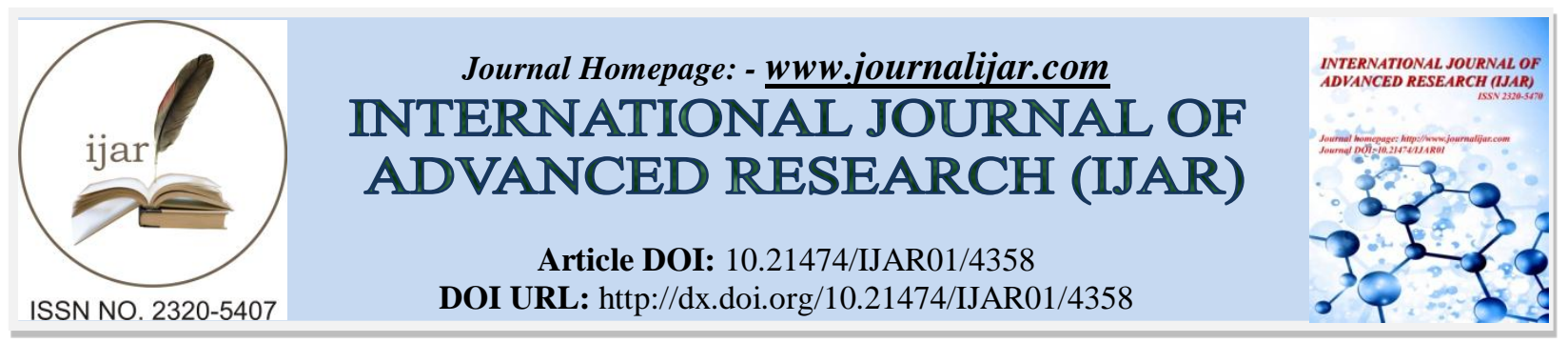

RESEARCH ARTICLE

\title{
SIMULATION OF FL SWITCHED Z-SOURCE INVERTER BASED PV GENERATION SYSTEM.
}

\author{
G. Trueman Savio Amalraj ${ }^{1}$ and Dr. P. Thangaraj. M. E. Ph.D ${ }^{2}$. \\ 1. Research Scholar Prist University, Tanjavur, Tamilnadu. \\ 2. Professor \& Head, Bannari Amman Institute of Technology,Sathyamangalam,Tamilnadu.
}

\section{Manuscript Info}

Manuscript History

Received: 15 March 2017

Final Accepted: 19 April 2017

Published: May 2017

Key words:-

Z-Source Inverter, Multi-Level

Inverters, THD, ANN, feedforward

\section{Abstract}

Solar Energy Systems (SES) are quite popular owing to their own merits. SES consist of DC to AC converters. In this paper, Z-Source inverter based SES has been proposed. The switching of these converters is currently addressed through soft computing techniques. The gate pulse required for switching are generated through Fuzzy Logic (FL). The proposed FL switching scheme has been simulated using MATLAB/Simulink and the results have been resented. The results depict that the proposed scheme has reduced THD of $8.92 \%$, compared to its conventional counterpart and can be used even under partial shadowing conditions of the SES.

Copy Right, IJAR, 2016,. All rights reserved.

\section{Introduction:-}

Solar Energy Systems (SES) are quite popular due to the reasons which include, pollution free environment, availability in abundant, noise less and low maintenance cost. The SES system consist of Photo Voltaic Systems (PV) that generate electricity from solar energy. The power generation capacity determines the size of the system, which makes it to be more robust and compact. Everyday there exists an advancement in the conversion technologies of solar power. Researchers concentrate widely on improving the quality of power converted and delivered from the source to the utilities. In SES, the problem that occurs mainly is the way to increase the output voltage. To increase it several units of solar panels are being connected in series. The main drawback is that it reduces the reliability and thereby affecting the efficiency of the system.

The PV cell converts the solar energy into DC voltage and it depends on various factors. The prime factor being the irradiance of the sunlight. The output of the PV cell is converted into AC through inverter and then fed to the consumer or to the grid. Multi-Level Inverters (MLI) are widely used to convert the DC to AC in the SES. Initially, the output of the PV module is strengthened using DC-DC converters.

In these MLI based SES modules, the output of the PV cell is modulated through DC-DC converters and then fed to the MLIs. Z-Source inverter is another type of inverter topology that doesn't require DC-DC converter. The recent investigations are focusing on the development of new strategies for DC-AC conversion, in order to improve the conversion efficiency. The conventional method is to step-up the AC output voltage through a step-up transformer. 3-Phase MLIs are also employed in the SES [1]. The problems associated with these conventional methods are electromagnetic interference, size, acoustic noise and high cost [2]. To overcome, these drawbacks, the Z-Source inverters have been suggested [3-5]. These inverters employ less number of switches compared to the conventional inverters. 
The model of the Z-source inverter has been developed and analyzed for its transient characteristics [6 \& 7]. The proper switching of the switches in the z-source inverter yields better performance and efficiency [8 - 10]. Fuzzy logic is a technique, that doesn't need mathematical model of the system [11-12]. It utilizes human expertise and 1it's a knowledge based system. In this paper, the Fuzzy Logic based Z-Source inverter has been proposed for improving the performance of the SES. The proposed scheme has been simulated using MATLAB/Simulink. A comparative analysis has been made between the conventional Pulse Width Modulated (PWM) Inverter and the proposed FL switched Z-Source Inverter scheme, to corroborate the performance of the proposed scheme.

\section{SES Configuration:-}

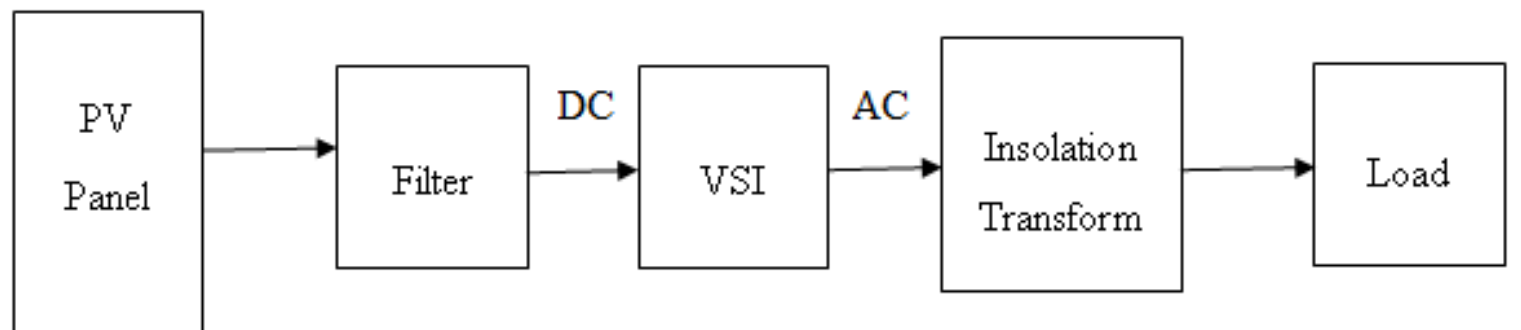

Fig.1:- Conventional VSI based SES

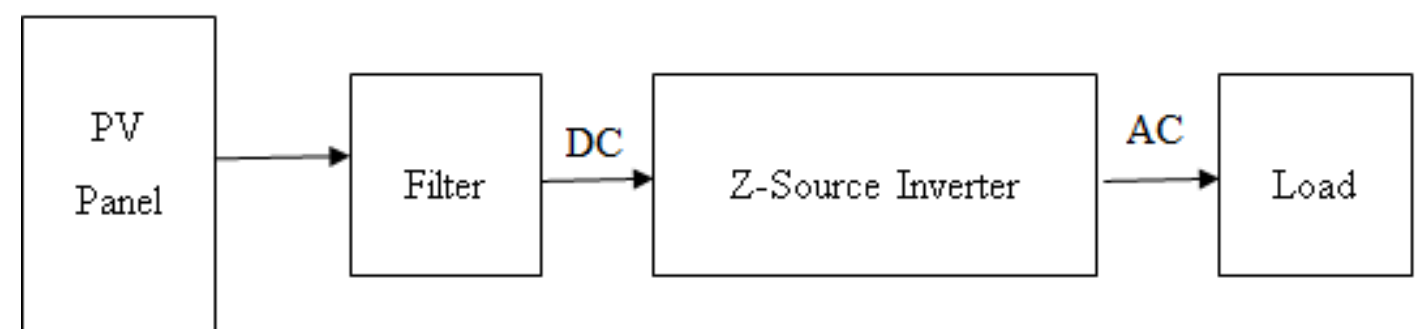

Fig. 2:- Z-Source Inverter based SES

Figures 1 and 2 depicts the system configuration of conventional and proposed Z-Source inverter based SES. The advantage of Z-Source topology is that it can either buck or boost the voltage/ current levels with a single circuit. This cannot be achieved through the PWM based Voltage Source Inverters (VSI). In this proposed system, the Zsource inverter acts as a boost converter and supplies sinusoidal voltage to the load.

It is generally known that the output voltage of PV array varies widely under different irradiance and environment temperature, the typical ratio of the maximum output voltage and the minimum is $2: 1$, and even bigger. Thus in order to get steady ac voltage, grid-connected PV system should have the ability to buck/boost voltage. What's more, to enhance the efficiency of PV array, grid-connected PV system also should have the ability to make PV array output maximum power. A model-based control algorithm can be used to control a switching matrix that connects a solar adaptive bank to a fixed part of the PV array. Similarly, dynamic electrical array reconfiguration can be used to improve the PV energy production during partial shadowing conditions. A controllable switching matrix can also be used between the PV generator and the central inverter to allow electrical reconnection of the available PV modules so that the maximum energy efficiency can be achieved. 


\section{Z-Source Inverter:-}

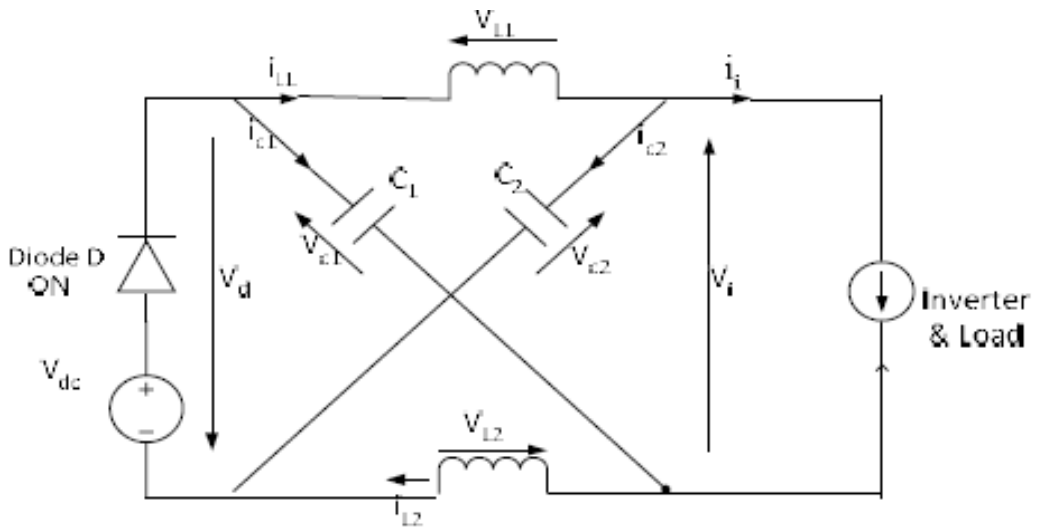

(a) Non-Shoot through state

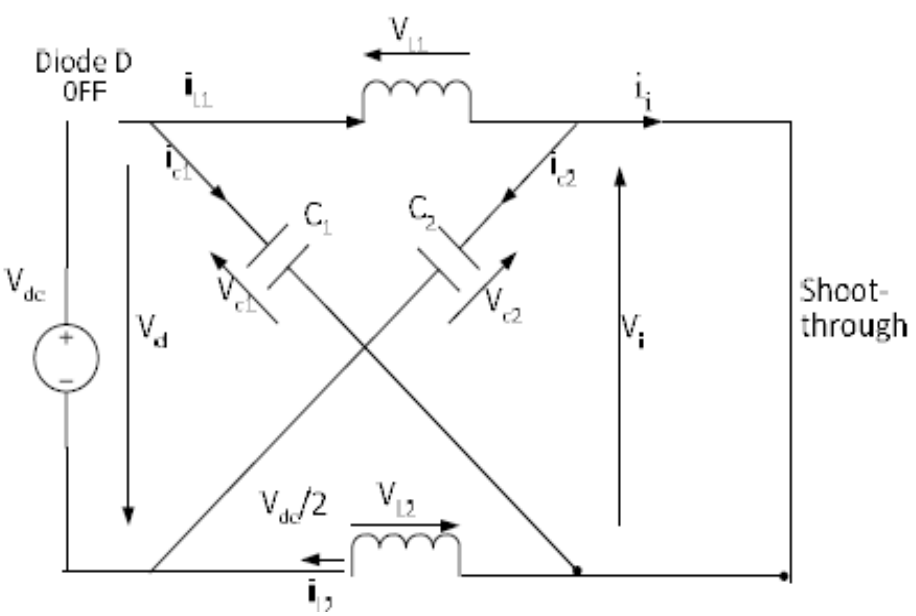

(b) Shoot through state

Fig. 3:- Equivalent circuit model of Z-Source Inverter

The main objective of static power converters is to produce an AC output waveform from a dc power supply. Impedance source inverter is an inverter which employs a unique impedance network coupled with the inverter main circuit to the power source. This inverter has unique features in terms of voltage (both buck \& boost) compared with the traditional inverters. A two port network that consists of a split-inductor and capacitors that are connected in X shape is employed to provide an impedance source (Z-source) coupling the inverter to the dc source, or another converter. The DC source/load can be either a voltage or a current source/load. Therefore, the DC source can be a battery, diode rectifier, thyristor converter, fuel cell, PV cell, an inductor, a capacitor, or a combination of those.

\section{Impedance Network:-}

The Z-source concept can be applied to all DC-to-AC, AC-to- DC, AC-to-AC and DC-to-DC power conversion. The output DC voltage fed to the Impedance source network which consists of two equal inductors (L1, L2) and two equal capacitors $(\mathrm{C} 1, \mathrm{C} 2)$. The network inductors are connected in series arms and capacitors are connected in diagonal arms .The impedance network, used to buck or boost the input voltage depends upon the boosting factor. This network also acts as a second order filter. This network should require less inductance and be smaller in size. Similarly capacitors required should be of low capacitance and smaller in size. This impedance network feeds constant impedance output voltage to the three phase inverter main circuit. Depending upon the gating signal, the inverter operates and this output is fed to the 3-phase ACload.

The Z-source inverter is analysed using voltage source inverter. The unique feature of the Z-source inverter is that the output ac voltage can be of any value between zero and infinity regardless of the input DC voltage. That is, the $\mathrm{Z}$-source inverter is a buck-boost inverter that has a wide range of obtainable voltage. The traditional voltage source 
and current source inverters cannot provide such features. The main feature of the Z-source inverter is implemented by providing gate pulses including the shoot-through pulses. Here to insert this shoot through state becomes the key point of the control methods. It is obvious that during the shoot-through state, the output terminals of the inverter are shorted and the output voltage to the load is zero. The output voltage of the shoot through state is zero, which is the same as the traditional zero states, therefore the duty ratio of the active states has to be maintained to output a sinusoidal voltage, which means shoot-through only replaces some or all of the traditional zero states.

\section{Mathematical Model of Z-Source Inverter:-}

Fig. 3 depicts the equivalent circuit model of Z-Source inverter under non-shoot through and shoot through state conditions. Assumptions made in the design are as follows:

$\mathrm{L} 1=\mathrm{L} 2$ and $\mathrm{C} 1=\mathrm{C} 2$. This results in a symmetrical Z-Source network, where the voltage across inductors and capacitors are as given in Equations $1 \& 2$.

$$
\begin{aligned}
& \mathrm{Vc1}=\mathrm{Vc} 2=\mathrm{Vc} \\
& \mathrm{V} 11=\mathrm{VL} 2=\mathrm{VL}
\end{aligned}
$$

During the shoot - through zero state for an interval (T0) during a switching cycle (TZ), VL=VC, Vd = 2VC, V0=0

Now consider that the inverter bridge is in one of the eight non-shoot-through states for an interval of T1, during the switching cycle,

$$
\mathrm{TZ} \mathrm{VL}=\mathrm{V} 0-\mathrm{VC}, \mathrm{V} 0=\mathrm{VC}-\mathrm{VL}=2 \mathrm{VC}-\mathrm{Vpv}
$$

Where $\mathrm{Vpv}$ is the output DC voltage of PV panel and $\mathrm{TZ}=\mathrm{T} 0+\mathrm{T} 1$. The average voltage of the inductors over one switching period $\mathrm{T}$ should be zero in steady state.

From Equations $3 \& 4$, the voltages across inductors and capacitors are obtained as

$$
\begin{gathered}
\mathrm{VL}=[\mathrm{T} 0 \mathrm{VC}+\mathrm{T} 1(\mathrm{Vpv}-\mathrm{VC})] / \mathrm{TZ}=0 \\
\mathrm{VC} / \mathrm{Vpv}=\mathrm{T} 1 /(\mathrm{T} 1-\mathrm{T} 0)
\end{gathered}
$$

The average DC link voltage is

$$
\mathrm{V} 0=[\mathrm{T} 1 /(\mathrm{T} 1-\mathrm{T} 0)] \mathrm{Vpv}
$$

The peak DC-link voltage across the inverter bridge is expressed in Equation 4 can be rewritten as:

Where, $\mathrm{B}=\mathrm{TZ} /(\mathrm{T} 1-\mathrm{T} 0)=1 /(1-2 \mathrm{~T} 0 / \mathrm{TZ}) \geq 1$

$$
\mathrm{V} 0=\mathrm{B} \cdot \mathrm{Vpv} \quad(8)
$$

The DC-link voltage is the boost factor resulting from the shoot-through zero state. The output voltage from the inverter is represented by

Here, $\mathrm{M}$ is the modulation index.

$$
\mathrm{Vac}=\mathrm{M} \mathrm{Vo} / 2
$$

From Equations $8 \& 9$, the output of the inverter is expressed as

$$
\mathrm{Vac}=\mathrm{M}^{*} \mathrm{~B}^{*} \mathrm{Vpv} / 2(10)
$$

Equation 10, states that the output can be efficiently controlled by controlling the buck-boost factor M*B. Many efficient algorithms have been proposed to control the buck boost factor, which in turn determines the switching sequences of the switches in the Z-Source network.

\section{FL based Switching Scheme:-}

Fuzzy Logic Controller (FLC) is a rule based decision making system used for process control. They are knowledge based systems. Based on the type of response required, the rules are framed. The fuzzy system consists of fuzzification, defuzzification, knowledge base (If-Then Rules) and inference system. Fuzzification is converting crisp values into fuzzy and defuzzification is the vice-versa of it. Mamtani and sugeno are the two methods of designing fuzzy systems. The difference between Mamtani and sugeno model is that sugeno model doesn't requires defuzzification module. But it is quite complicated.

\section{Membership Functions:-}

In this FL switching system the error and change in error are taken as parameters to frame the fuzzy rules. The mamtani method is used for framing fuzzy rules is used and the outputs are matched with it. The table 1 shows the rule base for framing the linguistic variables used in the system and table 2 shows the IF Then rules framed. 


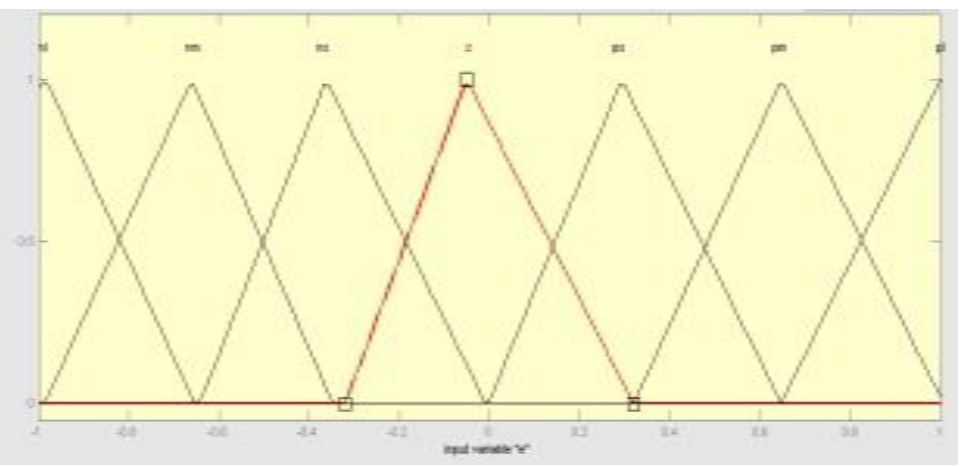

(a) Error e(t)

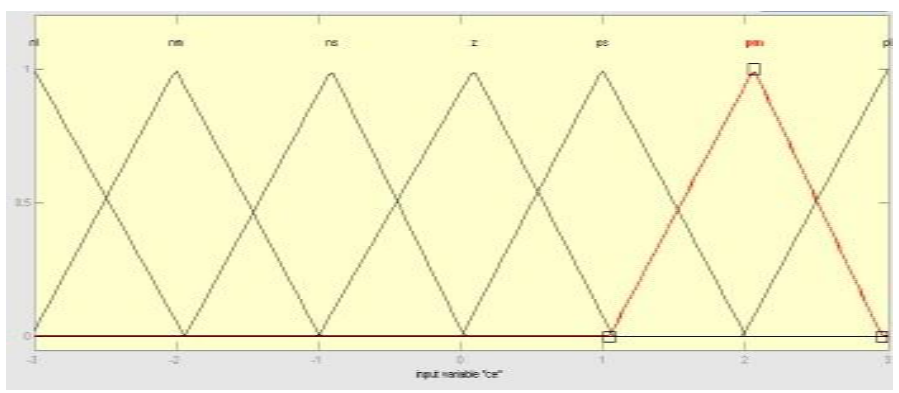

(b) Change in Error $\Delta \mathbf{e}(\mathbf{t})$

Fig. 4:- Membership functions.

Table 1:- linguistic variables for flc.

\begin{tabular}{|c|c|c|}
\hline Error e(t) & Change in error $\mathbf{\Delta e}(\mathbf{t})$ & Controller output u(t) \\
\hline NB & NB & NB \\
\hline NM & NM & NM \\
\hline NS & NS & NS \\
\hline ZO & ZO & ZO \\
\hline PS & PS & PS \\
\hline PM & PM & PM \\
\hline PB & PB & PB \\
\hline
\end{tabular}

Table 2:- If Then Rules For Flc.

\begin{tabular}{|c|c|c|c|c|c|c|c|c|}
\hline \multirow[t]{2}{*}{ Output u(t) } & & & & \multicolumn{2}{|c|}{ Error e(t) } & & & \\
\hline & & NB & NM & NS & $\mathrm{ZO}$ & PS & PM & PB \\
\hline \multirow{7}{*}{$\begin{array}{l}\text { Change in } \\
\text { error } \\
\Delta e(t)\end{array}$} & NB & NB & NB & NB & NB & NM & NS & $\mathrm{ZO}$ \\
\hline & NM & NB & NB & NB & NM & NM & $\mathrm{ZO}$ & PS \\
\hline & NS & NB & NB & NM & NS & NS & PS & PM \\
\hline & $\mathrm{ZO}$ & NB & NM & NS & $\mathrm{ZO}$ & $\mathrm{ZO}$ & PM & PB \\
\hline & PS & NM & NS & $\mathrm{ZO}$ & PS & PS & PB & PB \\
\hline & PM & NS & $\mathrm{ZO}$ & PS & PM & PM & PB & PB \\
\hline & PB & $\mathrm{ZO}$ & PS & PM & PB & PB & PB & PB \\
\hline
\end{tabular}




\section{Simulation Results and Discussions:-}

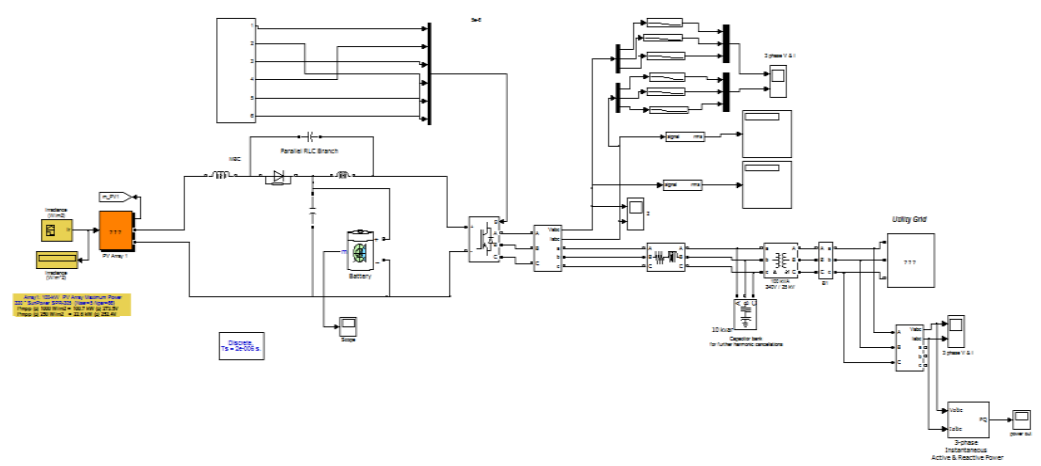

Fig. 5:- Simulation Model of proposed Z-Source Inverter.

Fig. 5 portrays the MATLAB/Simulink model of the proposed FL switched Z-Source Inverter scheme. The output of the inverter voltage and the load current are shown in Figs. 6(a) and 6(b) respectively. the output depicts that the current and voltage are found to be sinusoidal. The corresponding FFT analysis has been depicted in Fig. 7.

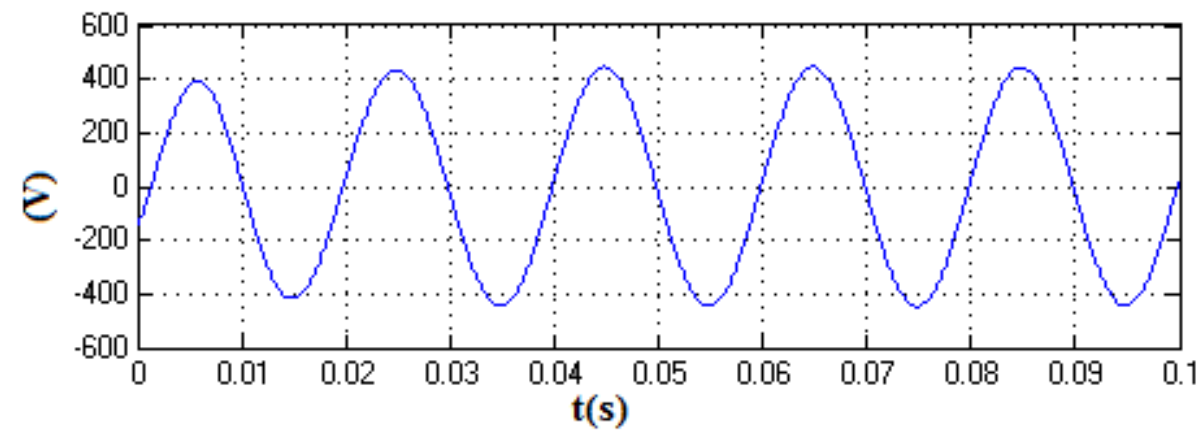

(a) Voltage

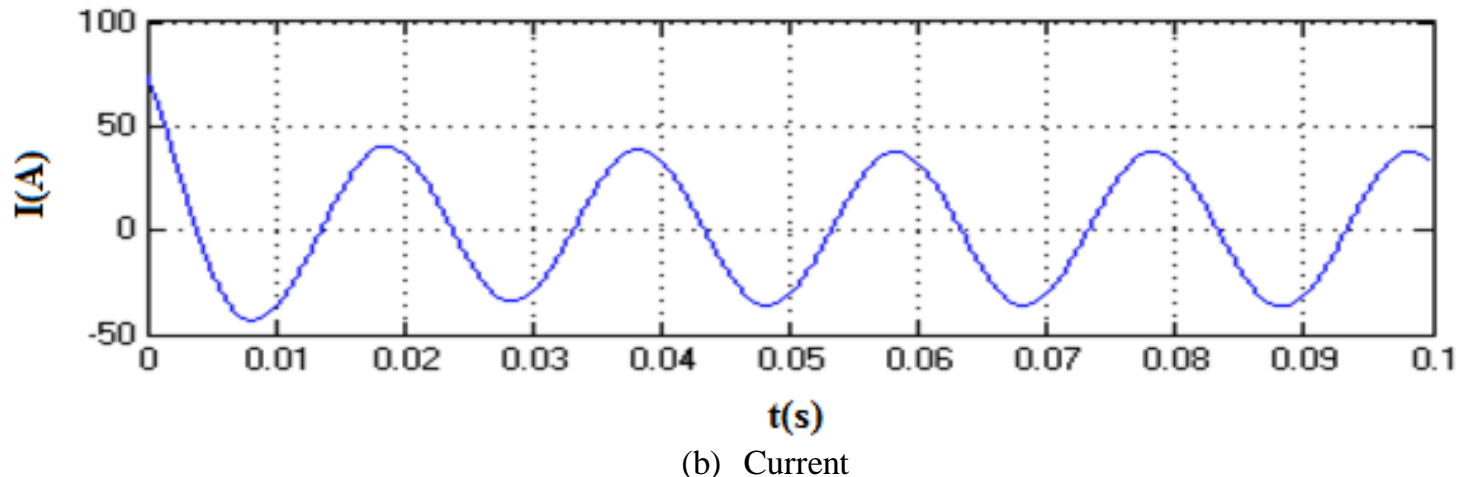

Fig. 6:- Simulated output of FL Switched Z-Source Inverter. 


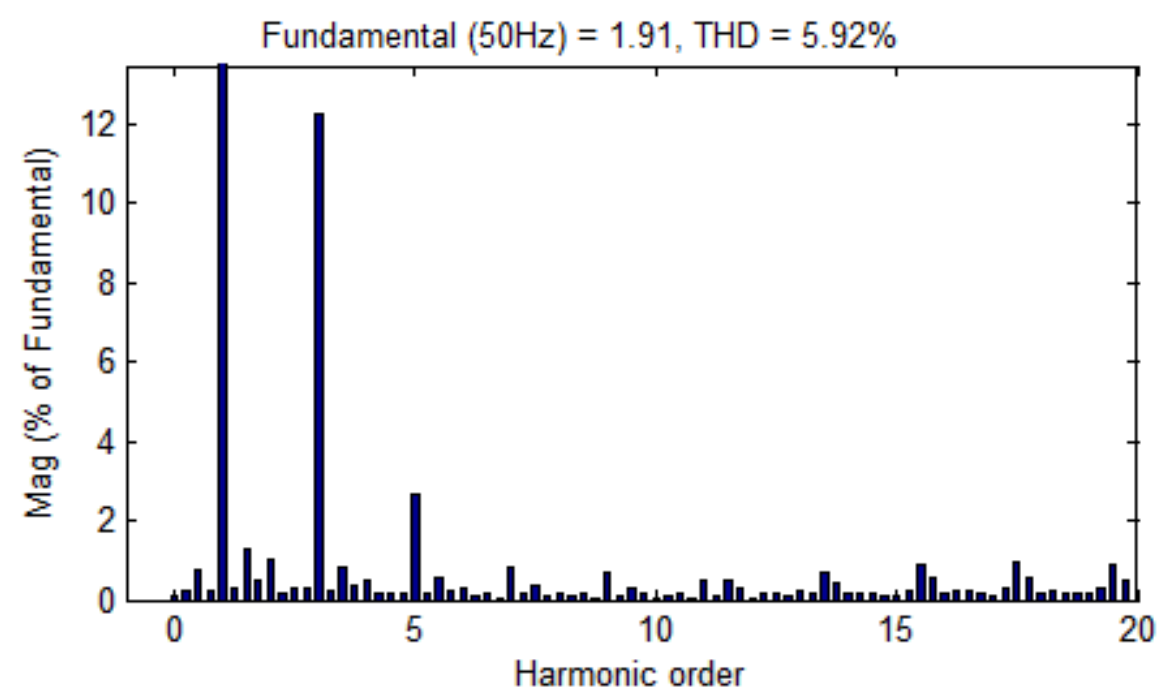

Fig 7:- FFT analysis of Z-Source Inverter.

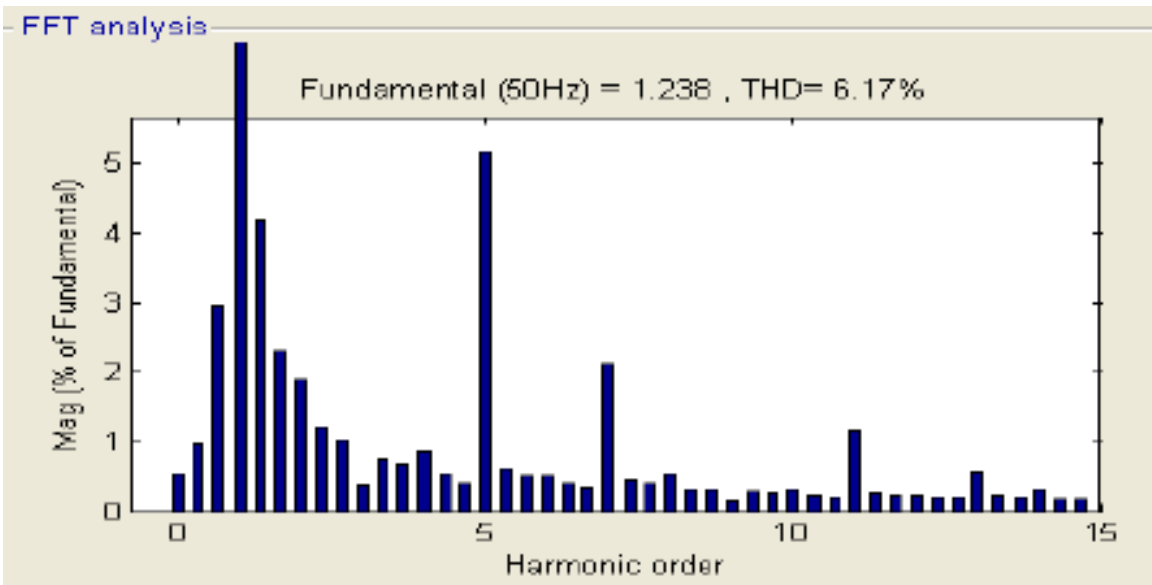

Fig 8:- FFT Analysis of PWM VSI.

Figures $7 \& 8$ shows the FFT analysis of the simulated outputs. The conventional scheme resulted in $6.71 \%$ of THD. The THD of FL switched scheme has been found to be 5.92\% which is reduced compared to the conventional PWM scheme.

\section{Conclusion:-}

The Z-Source inverter topology with FL based switching scheme has been modeled analyzed and simulated for the solar energy systems. The results and the corresponding FFT analysis show that the proposed FL switched Z-Source Inverter based scheme has resulted in reduced THD. The output of the system has been observed to be more sinusoidal. The THD of the proposed scheme is $5.92 \%$, whereas the conventional PWM scheme resulted in $6.17 \%$. In this way, it is evident that the proposed inverter topology has an edge over the conventional scheme. Hence, it can be effectively used even when the SES is subjected to partially shadowing conditions. 


\section{References:-}

1. Eftichios Koutroulis, Kostas Kalaitzaki and Nicholas C.Voulgaris, Development of a Microcontroller-Based, Photovoltaic Maximum Power Point Tracking Control System, IEEE Trans. On Power Electrons Vol.16, No.1, Jan. 2001, pp $46-54$.

2. H.Rostami and D.A.Khaburi, Neural Networks Controlling for Both the DC Boost and AC Output Voltage of Z-Source Inverter, IEEE Conference, 2010, pp 135 - 140.

3. Rathika, S.; Kavitha, J.; Paranjothi, S.R., "Embedded control Z-source inverter fednduction motor" : IEEE Conference, INCACEC 2009. Pp 1-7.

4. F. Z. Peng, "Z-source inverter," IEEE Tran. Ind. Appl., vol. 39 no2, pp. 504-510, Mar./Apr. 2003

5. Tang, Y., Xie, S.J., Zhang, C.H., Xu, Z.G.: 'Improved Zsource inverter with reduced Z-source capacitor voltage stress and soft-start capability', IEEE Trans. Power Electron., 2009, 24, (2), pp. 409-415

6. F.Z.Peng,M.Shen,A.Joseph,L.M.Tolbert,D.J.Adams, "Maximum Constant Boost Control of the Z-Source Inverter", In. proc.IEEE IAS'04,2004.

7. Zare,Farus and Adabi,Jafar,"Hysteresis Band Current Control for a Single PhaseZ-Source Inverter with Symmetrical and Asymmetrical Z-network", In proceedings Power Conversion Conference-PCC'07,pp.143148,Nagoya,Japan 2007.

8. M.Shen,F.Z.Peng,"Operating Modes and Characteristics of the Z-Source inverter with the Small Inductance”, in proc.IEEE IAS, 2005

9. U.Shajith Ali,V.Kamaraj,'Sine Carrier for fundamental Fortification in Three Phase Z-Source PWM Inverters', Modern Applied Science,Vol.4,No.1,pp73,January 2010.

10. Shen M S, Wang J, Joseph A, Peng F Z,Tolbert L M, and Adams D J, "Constant boost control of the Z-source inverter to minimize current ripple and voltage stress," May-Jun 2006, IEEE Transactions on Industry Applications, vol42, pp. 770-778.

11. Murugananth G and Vijayan S, "Development of Fuzzy controlled chopper drive for permanent magnetic dc Motor", Journal of Vibration and control, 2014.

12. Murugananth G, Muthukrishnan S, Samidurai K and Vijayan S, "Experiemntal Validation fo Fuzzy Tuned AWPI Controller-Based Chopper Driven PMDC Motor", Journal of Testing and Evaluation, vol. 43, Issue 6, 2015.

13. N.Vidhyarubini , G.Rohini ,"Z-source inverter for photovoltaic power generation system "proceedings of ICETECT 2011

14. B.Farhangi,Sh. Farhangi,"Application of Z-Source Converter in Photovoltaic Grid-Connected Transformerless Inverter", PELINCEC 2005 Conf.15-20 Oct.2005,Warsaw,Poland. 